\title{
How Tiered English Instruction Affects Reading Comprehension of Thai Students in Mixed-Ability EFL Classrooms
}

\author{
Piyawadee White (Corresponding author) \\ Faculty of Education, Chulalongkorn University \\ 254 Phayathai Road, Pathumwan, Bangkok 10330, Thailand \\ Tel: 66-8128-3800Ｅ-mail: piyawadee.white@gmail.com \\ Jutarat Vibulphol \\ Faculty of Education, Chulalongkorn University \\ 254 Phayathai Road, Pathumwan, Bangkok 10330, Thailand \\ Tel: 66-81824-5585Ｅ-mail: jutarat.v@chula.ac.th
}

Received: November 16, 2020

Accepted: December 14, 2020

Published: December 30, 2020

doi:10.5296/jei.v6i2.17942

URL: https://doi.org/10.5296/jei.v6i2.17942

\begin{abstract}
One challenge teachers have when teaching mixed-ability classrooms is ensuring that each student is appropriately supported and challenged based on their current ability. Tiering is an instructional strategy proposed in the Differentiated Instruction approach to address this issue. This article explores how an English reading course that tiered the content, process, and product affected the reading comprehension of ninth grade EFL students. The three elements were tiered to serve three groups of students - basic, grade-level, and advanced. Two parallel pretest and posttest were used to collect the data. The positive effects of the tiered instruction on the students' reading comprehension in this study suggest further implementation of tiered instruction in other EFL classrooms. Further research should explore how tiered instruction functions with different learner demographics and in other language skill settings.
\end{abstract}

Keywords: Tiered instruction, Differentiated instruction, Mixed-ability English classroom, Reading comprehension, EFL students 


\section{Introduction}

In most classrooms, especially at the basic education level, teachers are often challenged by the diversity of the students in the class - abilities, preferences, learning styles, and motivation, to name a few (Apairach \& Vibulphol, 2015; Bruner et al., 2015; Kuehn, 2020; Phairee et al., 2008; Vibulphol, 2016). The 'standardized' teacher-centered instructional approach may not support the students in such classrooms effectively (Loima \& Vibulphol, 2014, 2016; Suthipiyapathra et al., 2019; Vibulphol, 2016). Consequently, educational movements towards individualized, learning experiences have been observed in many countries around the world (Brown, 2003; Gregory \& Chapman, 2007; Smart et al., 2012; Wu \& Alrabah, 2009), Thailand included (Ministry of Education, 2008; Office of the National Education Commission, 1999). Since the enactment of the National Education Act of 1999 in Thailand, there has been numerous attempts to promote learner-centered instructional designs that cater to the needs of the individual learner throughout the country (Amkham \& Chinokul, 2010; Pinweha \& Chinwonno, 2010; Songchat \& Chinokul, 2017; Suthipiyapathra et al., 2019).

Over the years, teachers began to realize that by focusing on teaching to the middle, the majority of students in the classroom would struggle to have their needs met (Anderson, 2007). One systematic approach that has emerged in response to one-size-fits-all instruction's lackluster results is Differentiated Instruction (DI) (Tomlinson, 2001). In DI classrooms, the teacher acknowledges the unique needs of each student (Gregory \& Chapman, 2007) and employs a variety of teaching methods and techniques to vary the curriculum and instruction in such a way that all of the individual needs, interests, learning profiles, and readiness levels of the students are accommodated (Tomlinson, 1999, 2000, 2001, 2003; Tomlinson \& Eidson, 2003a, 2003b; Tomlinson \& Imbeau, 2010; Tomlinson \& Strickland, 2005).

Tiered instruction, among other DI strategies such as compacting, learning contracts, and flexible grouping, is implemented in differentiated classrooms to bridge the gap between students' current ability and what they are expected to learn (Bender, 2002; Coil, 2007; Narvaez et al., 2010; Pierce \& Adams, 2003, 2004, 2006; Turville et al., 2010). According to Pierce and Adams (2006), "a tiered lesson is a differentiation strategy that addresses a particular standard, key concept, and generalization, but allows several pathways for students to arrive at an understanding of these components based on their interests, readiness, or learning profiles" (p. 19).

Tomlinson (1999) suggested that three elements of instruction can be tiered in a lesson - content, process, and product (see also Pierce \& Adams, 2003, 2004, 2006). To adjust the complexity level of a tiered lesson, the Equalizer, a tool devised by Tomlinson (2001), can be implemented to help teachers differentiate a lesson in a mixed-ability classroom (Pierce \& Adams, 2006). According to Tomlinson (2001), the content can be altered in terms of the levels of difficulty, the process in terms of the levels of independence and pace of learning, and the product in terms of the task structure, leap in learning, foundation of information, abstractness, and number of facets.

Tiered instruction has been found to be an effective strategy for classrooms with diverse groups of learners (Bender, 2002; Coil, 2007; Narvaez et al., 2010; Pierce \& Adams, 2003, 2004, 2006; 
Turville et al., 2010). In the same line, tiered instruction has also been found to benefit second language (L2) learners in various aspects including overall learning achievement (Magableh \& Abdullah, 2020; Suthipiyapathra et al., 2019), listening skill (Pourdana \& Shahpouri Rad, 2017), speaking skill (García Fonseca \& Casallas Gordillo, 2016), reading skill (Aliakbari \& Haghighi, 2014; Natsir \& Asrawiah, 2013; Pasuy Pedroza \& Mendieta Aguilar, 2013), and writing skill (Amkham \& Chinokul, 2010). The majority of these previous studies, however, focused on tiering one or two instructional elements and not all three. Only a few studies on tiered instruction in reading classrooms have focused on tiering all three elements, most notably being Aliakbari and Haghighi (2014). Most other studies, however, have focused solely on tiering the product (e.g., Natsir \& Asrawiah, 2013; Pasuy Pedroza \& Mendieta Aguilar, 2013).

Despite the need for instructional strategies that support the diverse needs of students in 'big size' classrooms in Thailand, studies on DI in general, and tiered instruction in EFL classrooms specifically, are scarce. Two prominent studies on these topics were conducted by Amkham and Chinokul (2010), which focused on tiering writing instruction, and Suthipiyapathra et al. (2019), which focused on using DI integratively with the Universal Design Approach (UD) to support university students in an inclusive English foundation classroom. Therefore, this study sought to fill a void in the collective body of research and investigate how tiered instruction based on the students' readiness in reading could be implemented in an English reading classroom with mixed ability students. The research question investigated in this article was how the tiered English reading instruction might affect the reading comprehension of Thai EFL students.

\section{Method}

This study employed a one-group, pretest-posttest, quasi-experimental design. The tiered reading instruction was implemented in a ninth grade classroom in one public school in the northeastern region of Thailand in February 2020. Before and after the instruction, the students' reading comprehension was assessed using a comprehension test.

\subsection{Population and Participants}

The population in this study was secondary school students in public schools in Thailand. A convenient sampling technique was used to select the participants. One classroom with mixed ability ninth grade students in one public school in the north eastern region of Thailand that agreed to participate in the study was selected. Ninth graders were selected as the participants in this study because they were the last level of basic education required for all Thais (Ministry of Education, 2008).

There were 29 students, six males and 23 females participating in the study. The students were between 14 and 16 years of age. Before the study began, each student was given an information sheet describing the objectives of the study and the student's roles and involvement in the study. They were also made aware that their information would be kept confidential and that their participation was voluntary and would not affect their grades in any classes. Since the students were minors, their parents and guardians were also informed 
and asked for consent.

\subsection{Tiered English Reading Instruction}

The tiered English reading instruction in the present study was offered as an additional English course for ninth grade students in the participating school in the second semester of the 2019 academic year. The course consisted of eight two-hour lessons and was conducted over the period of two weeks. The students participated in the course on the voluntary basis during the school hours that the school arranged specially.

\subsubsection{Tiered Instructional Design Processes}

The tiered English reading instruction was developed based on the tiered instructional design process proposed by Pierce and Adams (2006) as follows.

Step 1: Identify the Grade Level and Subject

Ninth grade students were selected as the target audience of the course since ninth grade is the last level of the basic education required for all Thais (Ministry of Education, 2008). The target subject was English and the target skill was reading comprehension.

Step 2: Identify the Standard

To determine the standard or the learning outcomes of the course, interviews were conducted with one ninth grade English language teacher and one administrator from the academic administration office. The two informants recommended using the local curriculum framework standards, suggested by the Ministry of Education (2008) and the Secondary Educational Service Area (SESA) Office 31 (Secondary Educational Service Area Office 31, 2018), to determine the learning outcomes of the course.

Step 3: Identify the Key Concept and Essential Understanding

In order to effectively design the tiered instruction, key concepts and essential understanding were identified based on the local curriculum framework standards.

Step 4: Develop a Lesson that Addresses the Essential Understanding

To satisfy the needs of the participating school and align with the national standards, a tiered English reading course consisting of eight lessons was developed using local-related content. Each lesson was designed to improve the students' English reading comprehension ability through a variety of reading tasks (see Appendix A for a sample lesson plan).

Step 5: Identify the Necessary Background

To ensure that all students have an appropriate level of background knowledge about the local-related content, a pre-assessment was used to assess the students' background knowledge at the beginning of each lesson. The students were asked to self-organize into three groups, based on their perceived readiness: basic tier group, grade-level tier group, and advanced tier group. The readiness-based groups were based on the criteria shown in Table 1.

The grouping of the students into the basic, grade-level, and advanced tiers was not 
fixed - the students were asked to assess themselves before each lesson, so the students might choose to be in a different tier each time. Consequently, the number of students in each tier could not be predetermined but was instead dependent on the results of the students' pre-assessment. If the students were observed to have chosen a wrong tier, they were asked to reconsider a more appropriate tier for the lesson. To help manage classroom disruptions, the students were given a table sign to indicate whether or not they needed the teacher's assistance while working on the task.

Table 1. Readiness-based groups and criteria

\begin{tabular}{|l|l|}
\hline Tier Group & Criteria \\
\hline Basic & $\begin{array}{l}\text { Students who identify themselves as having no or a low level of background } \\
\text { knowledge in regards to the pre-assessment question }\end{array}$ \\
\hline Grade-level & $\begin{array}{l}\text { Students who identify themselves as having a medium level of background } \\
\text { knowledge in regards to the pre-assessment question }\end{array}$ \\
\hline Advanced & $\begin{array}{l}\text { Students who identify themselves as having a high level of background } \\
\text { knowledge in regards to the pre-assessment question }\end{array}$ \\
\hline
\end{tabular}

Step 6: Determine the Type of Tiering

This study aimed to support the students in mainstream classrooms in Thailand, which are mostly mixed abilities. Consequently, the instruction was tiered based on the students' readiness - the students' background knowledge relating to the content of a given lesson.

Step 7: Determine how many Tiers will be Needed

Three possible tiers were used when grouping the students in each lesson: basic tier, grade-level tier, and advanced tier. According to the Ministry of Education, grade ninth students are expected to achieve A2 proficiency level of the Common European Framework of Reference (CEFR) (Ministry of Education, 2014); therefore, the three tiers were aligned with the reading competence described in CEFR.

Step 8: Determine Which Part of the Lesson will be Tiered

The tiered reading instruction designed in this study was tiered based on the students' readiness in reading. Three tiers were used to group the students for each lesson and to differentiate the three elements of the instruction: the content - the readability of the reading materials, the process - the level of independence and pace of learning, and the product - the complexity of the post-reading tasks.

Each element of the instruction was tiered by adapting the Equalizer suggested by Tomlinson (2001) (see Appendix B for details). 
(a) Tiered by Content

The content for each lesson was centered around local themes about the province in which the participating school was located. The topics included tourist attractions, natural heritages, local performance arts, folk plays, famous historical people, folktales, dialects, and handcrafted products, which were aligned with the local curriculum framework standards, suggested by the Ministry of Education (2008) and the Secondary Educational Service Area (SESA) Office 31 (Secondary Educational Service Area Office 31, 2018). Authentic reading texts were then chosen from various sources including online articles, encyclopedias, brochures, and print advertisements.

Each lesson revolved around one reading text that was modified into three versions: basic, grade-level, and advanced, using the Flesch Reading Ease Readability. In Thailand, ninth grade students are expected to achieve A2 proficiency level of the Common European Framework of Reference (CEFR) (Ministry of Education, 2014). A student with A2 proficiency is expected to be able to read short simple texts; therefore, the content for all three versions of the texts were modified to fall within the 60.00 to 69.99 Flesch Reading Ease score range of 'Plain English' texts . Three steps were employed when modifying the texts (Saggion, 2017) including formulating an appropriate grade-level reading material, simplifying the grade-level reading material to basic level, and increasing the difficulty of the grade-level reading material to advanced level.

As a result, each version of the text differs in terms of the Reading Ease score, the average syllables per word and the average sentence length. For the basic tier, the reading text contained only simple sentence structures with one clause per sentence. The reading ease scores ranged between 69.00 and 69.99. This range represents the easiest part of "Plain English". For the grade-level tier, the reading texts contained a mix of simple sentence structures, complex sentence structures, and compound sentence structures. The reading ease scores ranged between 64.50 and 65.49. This range represents the middle part of "Plain English". Finally, for the advanced tier, the students were given reading texts that contained only complex and compound sentence structures with two to three clauses per sentence. The reading ease scores ranged between 60.00 and 60.99 . This range represents the most difficult part of "Plain English".

The criteria for modifying the texts was checked by an expert in linguistics and the content consistency of the three versions of the texts were checked by two native English speaking teachers. The experts agreed that the criteria were appropriate and the content of all three versions of the texts contained appropriate level of difficulty and consistency.

(b) Tiered by Process

In each reading lesson, three instructional stages were included-pre-reading, while-reading, and post-reading. The learning processes in the first two stages were tiered to differentiate the levels of teacher support and learning pace.

The pre-reading stage was tiered in terms of the level of independence. For the basic tier, the students received the highest level of teacher support. The teacher provided guidance with 
frequent checks for understanding and skill development. For the grade-level tier, the students received support from their peers with occasional checks from the teacher. Finally, for the advanced tier, the students were most independent. The teacher occasionally checked with them only to ensure that they were on track.

The pace of learning for the students during the while-reading stage was tiered in terms of speed. For the basic tier, the students were given the maximum time, allowing each learner flexibility to study at their own pace. For the grade-level tier, the students were given average pace of study, with a time limit and a time warning. Finally, for the advanced tier, the students were given full control over the pace of learning and could proceed to the post-reading task whenever they finished reading the texts.

\section{(c) Tiered by Product}

The post-reading task was tiered in terms of the structure, leap of knowledge, foundation of information, abstractness, and number of facets.

For the basic tier, the students were given a post-reading task that was fully structured and required them to make connections and apply ideas that were familiar to them. The task focused on only key information and had one single correct interpretation. For the grade-level tier, the students were given a post-reading task that was semi-structured with some guided information. The task required the students to make connections and apply ideas that were somewhat familiar to them. In addition to identifying the key information, the students were also expected to be able to make some implication. The answer includes more than one correct interpretation. Finally, for the advanced tier, the students were given a post-reading task that was open-ended and required decision-making and independence. The task required the students to make connections between different and unrelated concepts and stretch and bend the ideas to create original thoughts beyond the given examples. The task did not have only one single correct interpretation and required heavily on implication.

\section{Step 9: Develop Assessment}

The assessment employed in this study was ongoing formative assessment to keep track of the students' progress and gather feedback on the teaching at the end of each lesson. The purpose of ongoing formative assessment was not to compare the students' performance with one another but instead, to determine the area for improvement of each student and use the information to improve their future learning experiences. To ensure that the students were assessed on only their reading comprehension ability, not the writing ability, spelling and grammatical mistakes were ignored and not taken into consideration.

Before implementing the tiered English reading instruction, sample lesson plans and their supplementary materials were checked by three ELT experts and one ninth grade English teacher from the participating school. Necessary revisions were made according to their comments and the other lesson plans were then designed accordingly. In addition, one lesson plan was tried out with a group of ninth grade students that had the same characteristics with the participants. The sample lesson was implemented successfully and within the time frame. 


\subsubsection{Tiered Instructional Procedures}

In each lesson of the tiered English reading course, the lesson was divided into three consecutive stages: pre-reading, while-reading, and post-reading (see Appendix A for details).

Stage 1: Pre-reading

During the first stage, the students were introduced to a topic of the day as a whole class. The teacher began the instruction by providing a brief overview of the content to activate the students' prior knowledge.

After that, a pre-assessment task was conducted in to gauge the students' background knowledge of the subject at hand. The students were required to self-organize into three groups - basic tier, grade-level tier, and advanced tier-based on their readiness.

Next, the teacher introduced a reading strategy to the class and distributed a handout that contained step-by-step guidance of how to use a reading strategy and a short paragraph. The students then were given time to read the handout and practice using the reading strategy.

Finally, the teacher introduced new vocabulary to the students before they proceeded to read the text.

Stage 2: While-reading

At this stage, the students were given approximately 10-15 minutes to read the texts. In this present study, the role of the teacher was a facilitator. The teacher guided, assisted, and encouraged the students to be active learners.

Stage 3: Post-reading

After reading the texts, the students were given approximately 25-30 minutes to complete a reading task. The reading tasks focused on the use of the reading strategy learned at the beginning of the lesson. Anchor activities designed by the teacher were also provided at this stage for the students who completed the learning task at different times in order to minimize chaos in the classroom.

\subsection{Reading Comprehension Tests}

Two parallel versions of the English reading comprehension test were designed and used as the pretest and posttest to assess the students' reading comprehension before and after the instruction. Each test consisted of two passages and 18 comprehension questions.

The topics of the passages were in the same line with those used in the instruction-local content. The four passages were selected and modified using the steps suggested by Saggion (2017) to match with the level of reading difficulty for ninth grade students "plain English" (Flesch Reading Ease scores ranging from 64.50 to 65.49).

Three types of items, true-false, multiple-choice, and short answer, were used to assess the reading comprehension in three levels: literal comprehension (six items), interpretive comprehension (ten items), and critical comprehension (two items), since these are the 
expected levels of comprehension for ninth grade students, based on the reading-related indicators in the core curriculum (Ministry of Education, 2008).

The two versions of the tests were checked for validity by two English teachers and one university lecturer in ELT field. After the revision based on the experts' comments, the tests were piloted with a group of ninth grade students with the same characteristics and backgrounds as the participants. The scores from the pilot study were analyzed using Kuder-Richardson (KR-20), Pearson Correlation Coefficient, item difficulty (P-value), and item discrimination (ID). The results showed that the two tests were reliable and were paralleled in all aspects: reliability, consistency, difficulty index, and discrimination index so they could be used interchangeably.

\section{Results and Discussion}

The pretest and posttest scores were analyzed using descriptive statistics including mean scores and standard deviation. They were then analyzed using the Wilcoxon matched-pairs signed-rank test and effect size. Wilcoxon matched-pairs signed-rank test was employed as the normality assumption was not met and the sample size was small. The results of the analysis are shown in Table 2.

Table 2. Wilcoxon matched-pairs signed-rank test results $(n=29)$

\begin{tabular}{|c|c|c|c|c|c|c|}
\hline & & $\mathbf{N}$ & Mean Rank & Sum of Ranks & $\mathbf{Z}$ & $\mathbf{p}$ \\
\hline \multirow{4}{*}{ Posttest-Pretest (Overall) } & Negative Ranks & $3^{\mathrm{a}}$ & 4.50 & 13.50 & $-3.315^{\mathrm{b}}$ & $.001 *$ \\
\hline & Positive Ranks & $16^{\mathrm{b}}$ & 11.03 & 176.50 & & \\
\hline & Ties & \multicolumn{5}{|l|}{$3^{c}$} \\
\hline & Total & \multicolumn{5}{|l|}{22} \\
\hline \multirow{4}{*}{ Posttest-Pretest (Literal) } & Negative Ranks & $5^{\mathrm{a}}$ & 6.00 & 30.00 & $-1.164 b$ & .244 \\
\hline & Positive Ranks & $8^{\mathrm{b}}$ & 7.63 & 61.00 & & \\
\hline & Ties & \multicolumn{5}{|l|}{$9^{c}$} \\
\hline & Total & \multicolumn{5}{|l|}{22} \\
\hline \multirow{4}{*}{ Posttest-Pretest (Interpretive) } & Negative Ranks & $5^{\mathrm{a}}$ & 6.40 & 32.00 & $-2.149 b$ & $.032 *$ \\
\hline & Positive Ranks & $12^{\mathrm{b}}$ & 10.08 & 121.00 & & \\
\hline & Ties & \multicolumn{5}{|l|}{$5^{\mathrm{c}}$} \\
\hline & Total & \multicolumn{5}{|l|}{22} \\
\hline \multirow{4}{*}{ Posttest-Pretest (Critical) } & Negative Ranks & $2^{\mathrm{a}}$ & 4.50 & 9.00 & $-2.627 b$ & $.009 *$ \\
\hline & Positive Ranks & $11^{\mathrm{b}}$ & 7.45 & 82.00 & & \\
\hline & Ties & \multicolumn{5}{|l|}{$9^{c}$} \\
\hline & Total & \multicolumn{5}{|l|}{22} \\
\hline
\end{tabular}


As shown in Table 2, the students' overall reading comprehension and two levels of comprehension was significantly improved after learning in the tiered English reading instruction. The students' overall comprehension pretest score was significantly different from the posttest score at the significance level of $p<0.05$. The effect size was value was 0.96 , which indicated that the tiered English reading instruction enhanced the students' overall reading comprehension ability at a high level. Similar trends were shown in the pretest and posttest scores of the items measuring interpretative comprehension and critical comprehension. Interestingly, the scores of the items measuring literal comprehension, which is the lowest level of comprehension, were not significantly different in the two tests.

The findings in the present study demonstrated a success in using tiered reading instruction to enhance reading comprehension of EFL secondary school students in Thailand. The positive effects found in the present study are consistent with previous findings (e.g., Aliakbari \& Haghighi, 2014; Natsir \& Asrawiah, 2013; Pasuy Pedroza \& Mendieta Aguilar, 2013). The improvement of the reading comprehension, especially the two high levels of comprehension, suggests that all students, regardless of their existing reading ability, must have received adequate support during the instruction (cf. Gregory, 2011; Tomlinson, 2000). This lends support to the argument that tiered instruction can enhance the learning of students in mixed-ability classrooms (see also Aliakbari \& Haghighi, 2014; Amkham \& Chinokul, 2010; García Fonseca \& Casallas Gordillo, 2016; Magableh \& Abdullah, 2020; Natsir \& Asrawiah, 2013; Pasuy Pedroza \& Mendieta Aguilar, 2013; Pourdana \& Shahpouri Rad, 2017; Suthipiyapathra et al., 2019).

Considering that the reading instruction in this study was tiered in all three elements, the tiering of each element must have helped facilitate the reading of the students as explained by Tomlinson (2000). According to Tomlinson, tiered content can help all students achieve a high level of comprehension. Since the students in this study had a chance to choose a text with the readability that matched with their background knowledge in each lesson, their motivation to read and their reading comprehension must have been aided effectively (Gambrell, 2011; Olsen, 2017). In addition, tiered processes and tiered products can also help provide opportunities for all students to gain an understanding of the new knowledge in ways that are relatable with their current level of knowledge (Tomlinson, 2000). In this study, the students received different levels of teacher support, were allowed to study at different pace, and worked on the reading tasks that differed in terms of the structure, leap of knowledge, foundation of information, abstractness, and number of facets. As a result, their reading comprehension was significantly improved (cf. Aliakbari \& Haghighi, 2014; Natsir \& Asrawiah, 2013; Pasuy Pedroza \& Mendieta Aguilar, 2013).

In addition to the increase in the reading ability, the students expressed positive opinions about the tiered English reading instruction. They found the instruction to be fun, relaxing, and interesting. These positive effects are in line with a number of previous studies on differentiated instruction in Thailand (e.g., Amkham \& Chinokul, 2010; Suthipiyapathra et al., 2019) and elsewhere (e.g., Avci, Yuksel, Soyer, \& Balikcioglu, 2009; Bal, 2016; Danzi, Reul, \& Smith, 2008; Karadag \& Yasar, 2010; Senturk, 2018). Considering that the students in the tiered English reading instruction were given choices in the learning process, read the texts 
with the readability that matched with their reading ability, and received appropriate teacher support, their motivation in reading was thus increased, as discussed by Avci et al. (2009) and Bal (2016).

Based on the positive effects of this tiered English reading instruction on both the test scores and students' opinions shown in the present study, it can be concluded that differentiated instruction using tiering can shift away from a 'standardized' teacher-center classroom, which may not support students effectively (Loima \& Vibulphol, 2014; Suthipiyapathra et al., 2019; Vibulphol, 2016), to a student-centered classroom that caters to the needs of the individual learner (Gregory \& Chapman, 2007). The teacher transformed her role from being the center of knowledge to a learning designer and a mentor to help the students become autonomous learners (see also Tomlinson, 2001).

\section{Limitations and Suggestions for Further Research and Implementation}

Regardless of the 'intensive' nature of the course, the eight lessons were conducted every other day over the period of two weeks due to some schedule conflicts with other school activities, the tiered English reading instruction showed to have many positive effects on the students. Further studies and recommendations for implementation are therefore as follows:

First, the findings of the present study suggest that tiered reading instruction should be further implemented in EFL classrooms with mixed ability students. Tiering all three elements of a lesson was proved to be successful in this study; nevertheless, tiering the content was very time consuming. In this study, ready-made tiered reading materials on local content were not available, requiring teacher-produced materials. For other reading courses, ready-made tiered reading materials may be used instead, e.g., from the following websites http://www.readworks.org, https://www.commonlit.org, and https://www.tweentribune.com.

Second, investigating how the tiered instructional strategies may be used in different language skill lessons should also be considered since each language skill is different in nature and the students may require different kinds of support.

Lastly, since the design of this study does not allow a deep understanding of how the instruction affected different groups of learners, further research may investigate the development of the students who identified themselves in different tiers separately, in addition to observing the students as a whole class.

\section{References}

Aliakbari, M., \& Haghighi, J. K. (2014). On the effectiveness of differentiated instruction in the enhancement of Iranian learners reading comprehension in separate gender education. Procedia-Social and Behavioral Sciences, 98, 182-189. https://doi.org/10.1016/j.sbspro. 2014.03.405

Amkham, C., \& Chinokul, S. (2010). Effects of differentiated writing instruction by tiered assignments on writing ability of ninth grade students (Master's Thesis, Chulalongkorn University, Thailand). Retrieved from http://cuir.car.chula.ac.th/handle/123456789/32902 
Anderson, K. M. (2007). Tips for teaching: Differentiating instruction to include all students. Preventing School Failure, 51(3), 49-54. https://doi.org/10.3200/PSFL.51.3.49-54

Apairach, S., \& Vibulphol, J. (2015). Beliefs about language learning of Thai upper secondary school students in different educational contexts. PASAA, 50, 65-94. Retrieved from https:/files.eric.ed.gov/fulltext/EJ1088301.pdf

Bal, A. P. (2016). The effect of the differentiated teaching approach in the algebraic learning field on students' academic achievements. Eurasian Journal of Educational Research, 63, 185-204. https://doi.org/10.14689/ejer.2016.63.11

Bender, W. N. (2002). Differentiating instruction for students with learning disabilities: Best teaching practices for general and special educators. Thousand Oaks, CA: Corwin Press.

Brown, K. L. (2003). From teacher-centered to learner-centered curriculum: Improving learning in diverse classrooms. Education, 124(1), 49-54.

Bruner, D. A., Sinwongsuwat, K., \& Radic-Bojanic, B. (2015). EFL oral communication teaching practices: A close look at university teachers and A2 students' perspectives in Thailand and a critical eye from Serbia. English Language Teaching, 8(1), 11-20. https://doi.org/10.5539/elt.v8n1p11

Coil, C. (2007). Successful teaching in the differentiated classroom. Saline, MI: Pieces of Learning.

Danzi, J., Reul, K., \& Smith, R. (2008). Improving student motivation in mixed ability classrooms using differentiated instruction (Master's thesis, Saint Xavier University \& Pearson Achievement Solutions, Inc.). Retrieved from https://files.eric.ed.gov/fulltext/ ED500838.pdf

Gambrell, L. B. (2011). Seven rules of engagement: What's most important to know about motivation to read. Reading Teacher, 65(3), 172-178. https://doi.org/10.1002/TRTR.01024

García Fonseca, J. A., \& Casallas Gordillo, W. J. (2016). Differentiated instruction and oral tiered activities to impact al students' English level in a multilevel classroom (Master's thesis, Universidad de La Sabana). Retrieved from http://hdl.handle.net/10818/24260

Gregory, G. H. (2011). The best of Corwin: Differentiated instruction. Thousand Oaks, CA: Corwin Press.

Gregory, G. H., \& Chapman, C. (2007). Differentiated instructional strategies: One size doesn't fit all. Thousand Oaks, CA: Corwin Press.

Karadag, R., \& Yasar, S. (2010). Effects of differentiated instruction on students' attitudes towards Turkish courses: An action research. Procedia-Social and Behavioral Sciences, 9, 1394-1399. https://doi.org/10.1016/j.sbspro.2010.12.340

Kuehn, P. R. (2020). Teaching in Thailand: Discipline problems in the classroom. https://owlcation.com/academia/Teaching-in-Thailand-Discipline-Problems-in-a-Fifth-GradeEFL-Classroom 
Loima, J., \& Vibulphol, J. (2014). Internal interest or external performing? A qualitative study on motivation and learning of 9th graders in Thailand basic education. Journal of Education and Learning, 3, 194-203. https://doi.org/10.5539/jel.v3n3p194

Loima, J., \& Vibulphol, J. (2016). Learning and motivation in Thailand: A comparative regional study on basic education ninth graders. International Education Studies, 9(1), 31-43. https://doi.org/10.5539/ies.v9n1p31

Magableh, I. S. I., \& Abdullah, A. (2020). On the effectiveness of differentiated instruction in the enhancement of Jordanian students' overall achievement. International Journal of Instruction, 13(2), 533-548. https://doi.org/10.29333/iji.2020.13237a

Ministry of Education. (2008). The basic education core curriculum B.E. 2551 (A.D. 2008). Bangkok: Ministry of Education.

Ministry of Education. (2014). Policy of English language teaching and learning reformation. Bangkok: Ministry of Education.

Narvaez, L., Tomlinson, C. A., \& Brimijoin, K. (2010). Differentiation at work, k-5: Principles, lessons, and strategies. Thousand Oaks, CA: Corwin.

Natsir, R. Y., \& Asrawiah, A. (2013). Improving the students' reading comprehension using tiered tasks strategy. Exposure Journal, 2(1), 76-94. https://doi.org/10.26618/ejpbi.v2i1.784

Office of the National Education Commission. (1999). National Education Act of B.E. 2542 (A.D. 1999). Bangkok: Office of the National Education Commission.

Olsen, B. (2017). I feel trapped: Motivation, Engagement, and text choice with struggling readers (Master's thesis, The College at Brockport State University of New York, USA). Retrieved from http://digitalcommons.brockport.edu/ehd_theses/753

Pasuy Pedroza, N., \& Mendieta Aguilar, J. D. (2013). Exploring third graders' reading comprehension through the implementation of tiered products for differentiated instruction (Master's thesis, Universidad de La Sabana). Retrieved from http://hdl.handle.net/10818/9294

Phairee, C., Sanitchon, N., Suphanangthong, I., Graham, S., Prompruang, J., Groot, F. O. D., \& Hopkins, D. (2008). The teaching practicum in Thailand: Three Perspectives. TESOL Quarterly, 42(4), 655. https://doi.org/10.1002/j.1545-7249.2008.tb00154.x

Pierce, R. L., \& Adams, C. M. (2003). Teaching by tiering. Science and Children, 41(3), 30. Retrieved from https://eric.ed.gov/?id=EJ789644

Pierce, R. L., \& Adams, C. M. (2004). Tierdless lessons: One way to differentiate mathematics instruction. Gifted Child Today, 27(2), 58-65. https://doi.org/10.4219/gct-2004-133

Pierce, R. L., \& Adams, C. M. (2006). Differentiating instruction: A practical guide to tiered lessons in the elementary grades. Waco, TX: Prufrock Press Inc.

Pinweha, S., \& Chinwonno, A. (2010). The effects of differentiated speaking instruction using computer-mediated communication and project work on Thai undergraduate students' English 
speaking proficiency and communication strategies (Master's Thesis, Chulalongkorn University, Thailand). Retrieved from http://cuir.car.chula.ac.th/handle/123456789/29210

Pourdana, N., \& Shahpouri Rad, M. (2017). Differentiated instructions: Implementing tiered listening tasks in mixed-ability EFL context. Journal of Modern Research in English Language Studies, 4(1), 69-87. https://doi.org/10.30479/jmrels.2017.1566

Saggion, H. (2017) Automatic text simplification. Williston, VT: Morgan \& Claypool Publishers. https://doi.org/10.2200/S00700ED1V01Y201602HLT032

Secondary Educational Service Area Office 31. (2018). กรอบหลักสูตรระดับท้องถิ่น “ของดี เมืองโคราช" [Local curriculum framework "Things that Khorat is known for"]. Nakhon Ratchasima, Thailand: Secondary Educational Service Area Office 31.

Senturk, C. (2018). Investigation of impacts of differentiated instruction applied in a primary school in attitudes of students towards the course. Cypriot Journal of Educational Sciences, 13(2), 487-505. https://doi.org/10.18844/cjes.v13i2.3359

Smart, K. L., Witt, C., \& Scott, J. P. (2012). Toward learner-centered teaching: An inductive approach. Business Communication Quarterly, 75(4), 392-403. https://doi.org/10.1177/10805 69912459752

Songchat, P., \& Chinokul, S. (2017). Effects of English speaking instruction based on multiple intelligences theory on English speaking ability of seventh grade students. OJED, 12(4), 255-268. Retrieved from https://so01.tci-thaijo.org/index.php/OJED/article/view/140880/ 104397

Suthipiyapathra, S., Vibulphol, J., \& Prongsantia, S. (2019). Accommodation and adaptation in inclusive English classrooms with undergraduate students with and without hearing impairment. Journal of Education Studies, 47(1), 434-457. Retrieved from https://so02. tci-thaijo.org/index.php/EDUCU/article/view/179863

Tomlinson, C. A. (1999). The differentiated classroom: Responding to the needs of all learners. Upper Saddle River, NJ: Pearson Education.

Tomlinson, C. A. (2000). Differentiation of instruction in the elementary grades. Champaign, IL: ERIC Clearinghouse on Elementary and Early Childhood Education.

Tomlinson, C. A. (2001). How to differentiate instruction in mixed-ability classrooms (2nd ed.). Champaign, IL: ERIC Clearinghouse on Elementary and Early Childhood Education.

Tomlinson, C. A. (2003). Fulfilling the promise of the differentiated classroom: Strategies and tools for responsive teaching. Alexandria, VA: ASCD.

Tomlinson, C. A., \& Eidson, C. C. (2003). Differentiation in practice: A resource guide for differentiating curriculum, grades $k-5$. Alexandria, VA: ASCD.

Tomlinson, C. A., \& Eidson, C. C. (2003). Differentiation in practice: A resource guide for differentiating curriculum, grades 5-9. Alexandria, VA: ASCD. 
Tomlinson, C. A., \& Imbeau, M., B. (2010). Leading and managing a differentiated classroom. Alexandria, VA: ASCD.

Tomlinson, C. A., \& Strickland, C., A. (2005). Differentiation in practice: A resource guide for differentiating curriculum, grades 9-12. Alexandria, VA: ASCD.

Turville, J., Nickelsen, L., \& Allen, L. (2010). Differentiating by readiness: Strategies and lesson plans for tiered instruction, grades $k-8$. Larchmont, NY: Routledge.

Vibulphol, J. (2016). Students' motivation and learning and teachers' motivational strategies in English classrooms in Thailand. English Language Teaching, 9(4), 64-75. https://doi.org/ 10.5539/elt.v9n4p64

Wu, S. h., \& Alrabah, S. (2009). A cross-cultural study of Taiwanese and Kuwaiti EFL students' learning styles and multiple intelligences. Innovations in Education \& Teaching International, 46(4), 393-403. https://doi.org/10.1080/14703290903301826

\section{Appendix A}

\section{Sample of Lesson Plan}

\begin{tabular}{|c|c|c|c|}
\hline \multirow{2}{*}{$\begin{array}{l}\text { Instructional } \\
\text { Stage }\end{array}$} & \multicolumn{3}{|c|}{ Instructional Procedure } \\
\hline & Basic Tier & Grade-level Tier & \\
\hline & \multicolumn{3}{|c|}{$\begin{array}{l}\text { (Greetings) } \\
\text { - Teacher shows a short video clip and asks students to guess the topic of today's } \\
\text { lesson. } \\
\text { (Play a video clip adapted from https://www.youtube.com/watch?v=8rZTsQiFIw4. The } \\
\text { video clip shows different parts of Prasat Hin Phimai) }\end{array}$} \\
\hline \multirow[t]{2}{*}{$\begin{array}{l}\text { Pre-assessment } \\
\text { (5 Minutes) }\end{array}$} & \multicolumn{3}{|c|}{$\begin{array}{l}\text { (Pass around the ribbon pins) } \\
\text { - } \quad \text { Teacher makes sure each student has all } 3 \text { colors: yellow, blue, and green. } \\
\text { - } \quad \text { Teacher asks students "what is Prasat Hin Phimai famous for?" to determine how } \\
\text { much they know about Prasat Hin Phimai. } \\
\text { - Teacher explains to students that if they don't know what Prasat Hin Phimai is } \\
\text { famous for at all or have very little idea, they have to put a yellow ribbon pin on their } \\
\text { chest, if they have some ideas, they have to put a blue ribbon pin on their chest, and if } \\
\text { they have the answer of what Prasat Hin Phimai is famous for, they have to put a green } \\
\text { ribbon pin on their chest. } \\
\text { - } \quad \text { Teacher allows students to be seated with their team and stay in these teams } \\
\text { throughout the lesson. }\end{array}$} \\
\hline & \multicolumn{3}{|c|}{$\begin{array}{l}\text { (Pass around handout 1. In handout 1, there is a paragraph about Prasat Hin Phimai.) } \\
\text { - Teacher reads the paragraph about Prasat Hin Phimai and asks students to imagine if } \\
\text { they were reading the paragraph and a friend that walked by and asked what you were } \\
\text { reading about, what would they say? }\end{array}$} \\
\hline
\end{tabular}




\begin{tabular}{|c|c|c|c|}
\hline & \multicolumn{3}{|c|}{ Instructional Procedure } \\
\hline & Basic Tier & Grade-level Tier & Advanced Tier \\
\hline \multirow[t]{5}{*}{$\begin{array}{l}\text { Pre-reading } \\
\text { (40 Minutes) }\end{array}$} & \multicolumn{3}{|c|}{$\begin{array}{l}\text { - Teacher asks students to share some answers and asks what strategy was used. } \\
\text { - } \quad \text { Teacher introduces Get the Gist strategy. } \\
\text { - } \quad \text { Teacher explains that Get the Gist strategy is a reading strategy that helps identify } \\
\text { the main idea of a paragraph or a short passage and the Gist or the main idea is the most } \\
\text { important information of a paragraph. } \\
\text { (Pass around the double-sided table sign) } \\
\text { - } \quad \text { Teacher explains to students that when they work on a task, place the "Please help!" } \\
\text { sign on their table if they need help from the teacher and if they are working on the task } \\
\text { just fine, they need to place the "I'm working on it!" sign on their table. } \\
\text { (Pass around handout } 2 \text {. In handout } 2 \text {, there are } 2 \text { pages consisting of the step-by-step } \\
\text { guidance of how to use Get the Gist strategy and the answer key which is covered by } \\
\text { crayon) } \\
\text { - Teacher asks students to study handout } 2 \text { carefully and answer the questions on the } \\
\text { handout. } \\
\text { - Teacher explains that for yellow team, students are going to sit with the teacher and } \\
\text { we will do this together. For blue team, students need to find a partner and work in pairs. } \\
\text { For green team, students will work on handout } 2 \text { independently. } \\
\text { - Teacher explains that for blue and green team, when they're finished with the } \\
\text { handout, they can proceed to look at the answer key on the next page. }\end{array}$} \\
\hline & $\begin{array}{l}\text { (Students sit and study } \\
\text { handout } 2 \text { with the teacher) }\end{array}$ & $\begin{array}{l}\text { (Students sit and study } \\
\text { handout } 2 \text { with a partner) }\end{array}$ & $\begin{array}{l}\text { (Students sit and study } \\
\text { handout } 2 \text { individually) }\end{array}$ \\
\hline & \multicolumn{3}{|c|}{ - $\quad$ Teacher asks students to share some answers. } \\
\hline & \multicolumn{3}{|c|}{$\begin{array}{l}\text { - Teacher introduces new vocabulary (historical park, influence, tourist attractions, } \\
\text { and statues) by showing some sample pictures and asking students to help come up with } \\
\text { a definition. Later, teacher presents two sample sentences that contain the vocabulary to } \\
\text { help students understand the words better. } \\
\text { - Teacher asks students to do a quick vocabulary check by matching a picture with its } \\
\text { correct word. }\end{array}$} \\
\hline & \multicolumn{3}{|c|}{$\begin{array}{l}\text { - Before reading the text, teacher explains to students that for yellow team, they are } \\
\text { going to sit with the teacher while they read. For blue team, they are going to read with } \\
\text { their partner that they paired up with before. For green team, they are going to read the } \\
\text { text individually. } \\
\text { - Teacher explains that students are going to use Get the Gist strategy to help them } \\
\text { identify the main idea of the text when they read. }\end{array}$} \\
\hline & $\begin{array}{l}\text { (Students read the text on } \\
\text { Worksheet } A \text { with a full } \\
\text { teacher assistance) }\end{array}$ & $\begin{array}{l}\text { (Students read the text on } \\
\text { Worksheet B with a partner } \\
\text { while the teacher checks in } \\
\text { once a while if needed) }\end{array}$ & $\begin{array}{l}\text { (Students read the text on } \\
\text { Worksheet C independently } \\
\text { while the teacher checks in } \\
\text { once a while if needed) }\end{array}$ \\
\hline
\end{tabular}




\begin{tabular}{|c|c|c|c|}
\hline \multirow{2}{*}{$\begin{array}{l}\text { Instructional } \\
\text { Stage }\end{array}$} & \multicolumn{3}{|c|}{ Instructional Procedure } \\
\hline & Basic Tier & Grade-level Tier & Advanced Tier \\
\hline \multirow[t]{3}{*}{$\begin{array}{l}\text { Post-reading } \\
\text { (35 Minutes) }\end{array}$} & \multicolumn{3}{|c|}{$\begin{array}{l}\text { - Teacher explains to students that the text they have just read is going to be published } \\
\text { in a local magazine and each student, as the best writer, is going to have to come up with a } \\
\text { headline for the article. } \\
\text { - } \quad \text { Teacher explains that a headline is a statement at the top of a page in a newspaper or } \\
\text { magazine and a headline has } 3 \text { characteristics which is short, covers the main idea, and } \\
\text { interesting to grab the reader's attention. } \\
\text { - } \quad \text { Teacher models how to write a headline based on the main idea from handout } 2 \text {. } \\
\text { - } \quad \text { Teacher reminds students that when they write a headline, the sentence has to be } \\
\text { short, covers key main idea of the text, and is interesting. } \\
\text { - } \quad \text { Teacher explains to students that if they finish the tasks early, they may go to the } \\
\text { silent corner and work on an extra task while waiting for their friends. }\end{array}$} \\
\hline & $\begin{array}{l}\text { (Students select a headline } \\
\text { for a local magazine that } \\
\text { describes the key elements } \\
\text { of Prasat Hin Phimai from } \\
\text { the statements provided on } \\
\text { Worksheet A) }\end{array}$ & $\begin{array}{l}\text { (Students write a headline } \\
\text { for a local magazine that } \\
\text { describes the key elements } \\
\text { of Prasat Hin Phimai from } \\
\text { the key words provided on } \\
\text { Worksheet B) }\end{array}$ & $\begin{array}{l}\text { (Students write a headline } \\
\text { for a local magazine that } \\
\text { describes the key elements } \\
\text { of Prasat Hin Phimai on } \\
\text { Worksheet } C \text { ) }\end{array}$ \\
\hline & \multicolumn{3}{|c|}{$\begin{array}{l}\text { - Teacher asks students to share their work by putting them up on the board. } \\
\text { - } \quad \text { Teacher and students walk around to read each other's work. }\end{array}$} \\
\hline $\begin{array}{l}\text { Conclusion } \\
\text { ( } 5 \text { Minutes) }\end{array}$ & \multicolumn{3}{|c|}{$\begin{array}{l}\text { - Teacher calls for a few volunteers to share with the class what they have learned } \\
\text { today. } \\
\text { - Teacher summarizes that what they have learned today is that that when they read } \\
\text { something, they don't need to try to understand every single word. They can use a reading } \\
\text { strategy like 'Get the Gist' to help identify only the main idea of a text. }\end{array}$} \\
\hline
\end{tabular}

\section{Appendix B}

Tiered Instructional Design (adapted from Tomlinson, 2001)

\begin{tabular}{|c|c|c|c|}
\hline Aspect & Basic Tier & Grade-Level Tier & Advanced Tier \\
\hline \multicolumn{4}{|c|}{ Tiered Content } \\
\hline $\begin{array}{l}\text { Simple to } \\
\text { Complex }\end{array}$ & $\begin{array}{l}\text { - } \quad \text { Flesch Reading } \\
\text { Ease scores between } \\
69.00 \text { to } 69.99 \\
\text { - } \quad \text { Simple sentence } \\
\text { structures }\end{array}$ & $\begin{array}{l}\text { - Flesch Reading Ease } \\
\text { scores between } 69.00 \text { to } \\
69.99 \\
\text { - } \quad \text { A mix of simple, } \\
\text { complex, and compound } \\
\text { sentence structures }\end{array}$ & $\begin{array}{l}\text { - Flesch Reading Ease } \\
\text { scores between } 69.00 \text { to } \\
69.99 \\
\text { - } \quad \text { Only complex and } \\
\text { compound sentence structures }\end{array}$ \\
\hline
\end{tabular}




\begin{tabular}{|c|c|c|c|}
\hline Aspect & Basic Tier & Grade-Level Tier & Advanced Tier \\
\hline \multicolumn{4}{|c|}{ Tiered Process } \\
\hline $\begin{array}{l}\text { Dependence to } \\
\text { Independence }\end{array}$ & $\begin{array}{l}\text { - Students learn a } \\
\text { reading comprehension } \\
\text { strategy with teacher } \\
\text { assistance. }\end{array}$ & $\begin{array}{l}\text { - Students learn a } \\
\text { reading comprehension } \\
\text { strategy in pairs. }\end{array}$ & $\begin{array}{l}\text { - Students learn a reading } \\
\text { comprehension strategy } \\
\text { independently. }\end{array}$ \\
\hline Slow to Quick & $\begin{array}{l}\text { - Students are given } \\
\text { the maximum pace of } \\
\text { learning. }\end{array}$ & $\begin{array}{l}\text { - Students have control } \\
\text { over the pace of learning, } \\
\text { with a time limit and a } \\
\text { time warning. }\end{array}$ & $\begin{array}{l}\text { - Students have control } \\
\text { over the pace of learning, } \\
\text { without a time limit }\end{array}$ \\
\hline \multicolumn{4}{|c|}{ Tiered Product } \\
\hline $\begin{array}{l}\text { Structured to } \\
\text { Open-ended }\end{array}$ & $\begin{array}{l}\text { - } \quad \text { Reading tasks } \\
\text { contain a structured } \\
\text { template and } \\
\text { step-by-step directions }\end{array}$ & $\begin{array}{l}\text { - Reading tasks contain } \\
\text { a semi-structured template } \\
\text { and step-by-step directions }\end{array}$ & $\begin{array}{l}\text { - Reading tasks contain an } \\
\text { open-ended template that } \\
\text { requires decision-making }\end{array}$ \\
\hline $\begin{array}{l}\text { Small Leap to } \\
\text { Greater Leap }\end{array}$ & $\begin{array}{l}\text { - Reading tasks does } \\
\text { not require students to } \\
\text { make connections } \\
\text { among ideas. }\end{array}$ & $\begin{array}{l}\text { - Reading tasks require } \\
\text { students to make } \\
\text { connections among ideas } \\
\text { that are somewhat familiar } \\
\text { to them. }\end{array}$ & $\begin{array}{l}\quad \text { Reading tasks require } \\
\text { students to make connections } \\
\text { among far-flung fields and } \\
\text { ideas. }\end{array}$ \\
\hline $\begin{array}{l}\text { Foundational to } \\
\text { Transformational }\end{array}$ & $\begin{array}{l}\text { - Reading tasks } \\
\text { require students to apply } \\
\text { ideas in a way that is } \\
\text { similar to the examples } \\
\text { presented in class. }\end{array}$ & $\begin{array}{l}\text { - Reading tasks require } \\
\text { students to apply ideas in a } \\
\text { way that is somewhat } \\
\text { similar to the examples } \\
\text { presented in class. }\end{array}$ & $\begin{array}{l}\text { - Reading tasks require } \\
\text { students to stretch and bend } \\
\text { ideas to create a new thought } \\
\text { beyond the examples } \\
\text { presented in class. }\end{array}$ \\
\hline $\begin{array}{l}\text { Concrete to } \\
\text { Abstract }\end{array}$ & $\begin{array}{l}\text { - Reading tasks } \\
\text { focus on only key } \\
\text { information. }\end{array}$ & $\begin{array}{l}\text { - Reading tasks focus } \\
\text { on key information and } \\
\text { implications. }\end{array}$ & $\begin{array}{l}\text { - } \quad \text { Reading tasks focus on } \\
\text { implications. }\end{array}$ \\
\hline $\begin{array}{l}\text { Single Facet to } \\
\text { Multiple Facets }\end{array}$ & $\begin{array}{l}\text { - Reading tasks } \\
\text { contain one single right } \\
\text { answer. }\end{array}$ & $\begin{array}{l}\text { - } \quad \text { Reading tasks contain } \\
\text { a few right answers. }\end{array}$ & $\begin{array}{l}\text { - Reading tasks does not } \\
\text { contain fixed answers and can } \\
\text { be answered in many ways. }\end{array}$ \\
\hline
\end{tabular}

\section{Copyright Disclaimer}

Copyright for this article is retained by the author(s), with first publication rights granted to the journal.

This is an open-access article distributed under the terms and conditions of the Creative Commons Attribution license (http://creativecommons.org/licenses/by/3.0/). 